\title{
INCOME BUDGETS EVALUATION OF SELECTED COMMUNES OF POMORSKIE VOIVODSHIP IN POLAND FROM THE TAX ON MEANS OF TRANSPORT
}

\author{
Cezary Szydłowski ${ }^{1}$
}

\begin{abstract}
Local government in Poland at the commune level has various sources of own income, one of them being the tax on means of transport. The need for communes to carry out many tasks requires ensuring income to the local budget at a sufficiently high level. The risk of a decrease in income to the budgets of communes caused by the worsening of the economic situation as a result of an epidemic makes it necessary to assess the sources of communes' income. An audit, which evaluates selected areas of activity of a given organization, is a useful tool. The main objective of the research for the purposes of this publication was to assess the level of income to the budget of selected municipalities from the tax on means of transport and its share in the total income of municipalities. In addition, changes in the level of income to the budgets of the surveyed municipalities in 2016-2019 were verified. Moreover, the article presents the essence and importance of audit in the assessment of revenue to the municipal budget. The article uses a case study, an analytical method, an application method, a method of examining source documents and a literature review as the research methods. The analysis of budget revenues of selected communes of Pomorskie Voivodship in Poland showed that the tax on means of transport constitutes a small percentage share in total budget revenues (below 1\% of total budget revenues). In addition, a significant decrease in revenues from this tax to the budgets of 11 surveyed municipalities was observed in the surveyed period 2016-2019. The analysis also revealed fluctuations in the municipalities' revenues from the tax on means of transport, which make it difficult to forecast revenues. It should also be noted that municipalities apply certain discounts and preferences when setting the amount of the tax on means of transport, which also reduce the revenue of the municipality. The assessment of revenues to municipalities' budgets from the tax on means of transport indicates that further analyses of revenues from individual local taxes and charges should be carried out in order to identify potential risks and threats to the financial economy of municipalities in Poland.
\end{abstract}

Key words: audit, budget revenues, local tax, public sector, local government, tax on means of transport, public finance.

JEL Classification: $\mathrm{H} 71, \mathrm{H} 83$

\section{Introduction}

The implementation of public tasks by local government requires financial resources, which are obtained from public levies. Valid in Poland, legal and systemic solutions have been established by three levels of local government (communes, county, voivodship), however, the basic unit of local government is the communes. The powers and tasks granted to the communes government require an appropriate system of financing them within the budget of the given communes unit. Local self-government in Poland at the communes level has various sources of its own income, which have been defined in relevant legal regulations. One of the basic sources of own revenues is the tax on means of transport, which constitutes a public tribute, its amount and the rules of collection from taxpayers are determined by the appropriate commune's legislative bodies. Planning expenses for the execution of tasks by the municipality also requires planning the level of the municipality's income for a given year from particular taxes and local fees. Therefore, it is necessary to assess revenues from a given tax, e.g., in the form of an audit. The assessment of the level of revenues to the local government budget is important in case of threats related to the deterioration of the country's economic situation, e.g., in connection with the occurrence of a global epidemic (World Economic Outlook, IMF, April 2020). Economic problems associated with the

Corresponding author:

${ }^{1}$ University of Łódź, Poland.

E-mail: cezary.szydlowski@uni.lodz.pl

ORCID: https://orcid.org/0000-0002-7454-2908 
crisis, affect the reduction of income to the municipal budget. The results of the analysis may allow to take appropriate remedial actions to improve local tax collection.

The aim of the research is to assess the level of municipalities' revenues from the tax on means of transport and its share in the total revenues of municipalities. The research was conducted on the basis of selected 11 coastal urban and rural municipalities of Pomorskie Voivodship in Poland. Moreover, the publication was intended to show that an audit of the assessment of income to the commune's budget can be an important source of financial information, which will enable communes to take corrective actions.

\section{Research methods}

The article uses a case study, an analytical method, an application method and a method of examining source documents (reports on the implementation of commune budgets in a given year and $\mathrm{Rb}$ $27 \mathrm{~s}$ reports containing the amounts of obtained commune income in a given year), a literature review as the research methods. The study covered selected coastal urban and rural communes of Pomorskie Voivodship in Poland. The choice of the commune was determined by its location and availability of data for the study. The surveyed time horizon covered the years 2016-2019.

\section{Tax on transport equipment as revenue for the municipal budget}

Local government in Poland is classified as a public finance sector unit (Law, 2009), whereas the tasks of communal self-government in Poland are defined by the Act on communal self-government (Law, 1990). Implementation of tasks at the commune level requires an appropriate system of financing mainly through own revenues to the budget in the form of public levies (Freire, Garzón, 2014). The Polish legislator has granted the local government the right to collect selected taxes and local fees (Chojna - Duch, 2003), it has also laid down rules for the participation of municipalities in other public levies charged by the government (Rudowicz, 2010). The systemic regulation of the income of local governments in Poland was established by an appropriate legal act, which specified that the source of the municipality's own income is, inter alia, the tax on means of transport (Law, 2003). The level of income depends on "the nature of the municipality, the level of social infrastructure - the economic activity of the commune, as well as the activities of the commune in terms of their acquisition" (Podstawka, 2010). The specific provisions specified that the tax on means of transport is subject to (Law, 1991):
1) lorries with a maximum permissible laden weight above 3.5 tons and below 12 tons;

2) lorries with a maximum permissible laden weight equal to or higher than 12 tons;

3) truck-tractors and ballast tractors adapted for the use with a semi-trailer or trailer with a maximum permissible laden weight of a vehicle combination from 3.5 tons to below 12 tons;

4) truck-tractors and ballast tractors adapted for the use with a semi-trailer or trailer with a maximum permissible laden weight of a vehicle combination equal to or higher than 12 tons;

5) trailers and semi-trailers, which together with a motor vehicle have a maximum permissible laden weight from 7 tons to below 12 tons, excluding those that are used solely in connection with agricultural activities carried out by an agricultural tax payer;

6) trailers and semi-trailers, which together with a motor vehicle have a maximum permissible laden weight equal to or higher than 12 tons, excluding those that are used solely in connection with agricultural activities carried out by an agricultural tax payer;

7) buses.

The legislation specified that the tax liability for the tax on means of transport covers natural persons and legal entities owning means of transport. According to the Act, the owners are also deemed to be organizational units without legal personality, for which the means of transport is registered, and owners of means of transport registered on the territory of Poland as entrusted by a foreign natural or legal person to a Polish entity (Law, 1991).

The amount of the tax on means of transport shall be determined by the municipalities taking into account various criteria such as environmental standards, capacity, number of seats on the bus, etc. However, the Polish legislation has set maximum rates of tax on means of transport that can be set by municipalities for a given year. Each year, the Minister of Finance publishes the maximum rates of individual taxes and local charges that may be set by municipalities. Statement of maximum rates of the tax on means of transport in Poland, valid for the years 2016-2019 are presented in Table 1.

The data in Table 1 indicate that in 2017 Minister of Finance for 2016, reduced the maximum rate of tax on means of transport in all tax bases by $0.9 \%$. However, the maximum rates of the tax on means of transport established for 2018-2019 were increased by the Minister of Finance in all tax bases (increase of rates by $1.9 \%$ in 2018 with respect to 2017 and increase of rates by $1.6 \%$ in 2019 with respect to 2018). The analysis of the maximum amount of individual property tax rates indicates that they differ significantly with respect to individual tax bases. These rates are the basis for municipalities to develop their own tax rates on means of transport for a given 
Table 1

Maximum rates of tax on means of transport in Poland for 2016-2019

\begin{tabular}{|c|c|c|c|c|c|c|c|c|}
\hline \multirow{2}{*}{ N. } & \multirow{2}{*}{$\begin{array}{l}\text { Tax base for the tax on means of transport } \\
\text { (pursuant to the Act of } 12 \text { January } 1991 \\
\text { on local taxes and charges) }\end{array}$} & \multicolumn{4}{|c|}{$\begin{array}{l}\text { Maximum tax rate } \\
\text { in a given year in PLN }\end{array}$} & \multicolumn{3}{|c|}{$\begin{array}{l}\text { Change in \% } \\
\text { (year-on-year) }\end{array}$} \\
\hline & & 2016 & 2017 & 2018 & 2019 & $\begin{array}{c}2017 / \\
2016\end{array}$ & $\begin{array}{r}2018 / \\
2017\end{array}$ & $\begin{array}{r}2019 / \\
2018\end{array}$ \\
\hline 1 & $\begin{array}{l}\text { Lorries with a maximum permissible laden weight above } \\
3.5 \text { tons and below } 5.5 \text { tons }\end{array}$ & 811.60 & 804.3 & 819.59 & 832.71 & $-0.90 \%$ & $1.90 \%$ & $1.60 \%$ \\
\hline 2 & $\begin{array}{l}\text { Lorries with a maximum permissible laden weight above } \\
5.5 \text { tons and below } 9 \text { tons }\end{array}$ & 1353.94 & 1341.76 & 1367.26 & 1389.14 & $-0.90 \%$ & $1.90 \%$ & $1.60 \%$ \\
\hline 3 & Lorries with a maximum permissible laden weight above 9 tons & 1624.72 & 1610.10 & 1640.70 & 1666.96 & $-0.90 \%$ & $1.90 \%$ & $1.60 \%$ \\
\hline 4 & $\begin{array}{l}\text { Lorries with a maximum permissible laden weight equal to or } \\
\text { higher than } 12 \text { tons }\end{array}$ & 3100.42 & 3072.52 & 3130.90 & 3181 & $-0.90 \%$ & $1.90 \%$ & $1.60 \%$ \\
\hline 5 & $\begin{array}{l}\text { Truck-tractors and ballast tractors adapted for the use with a } \\
\text { semi-trailer or trailer with a maximum permissible laden weight } \\
\text { of a vehicle combination from } 3.5 \text { tons to below } 12 \text { tons }\end{array}$ & 1895.48 & 1878.43 & 1914.13 & 1944.76 & $-0.90 \%$ & $1.90 \%$ & $1.60 \%$ \\
\hline 6 & $\begin{array}{l}\text { Truck-tractors and ballast tractors adapted for the use with a } \\
\text { semi-trailer or trailer with a maximum permissible laden weight } \\
\text { of a vehicle combination equal to } 36 \text { tons }\end{array}$ & 2396.41 & 2374.85 & 2419.98 & 2458.7 & $-0.90 \%$ & $1.90 \%$ & $1.60 \%$ \\
\hline 7 & $\begin{array}{l}\text { Truck-tractors and ballast tractors adapted for the use with a } \\
\text { semi-trailer or trailer with a maximum permissible laden weight } \\
\text { of a vehicle combination higher than } 36 \text { tons }\end{array}$ & 3100.42 & 3072.52 & 3130.90 & 3181 & $-0.90 \%$ & $1.90 \%$ & $1.60 \%$ \\
\hline 8 & $\begin{array}{l}\text { Trailers and semi-trailers, which together with a motor vehicle } \\
\text { have a maximum permissible laden weight from } 7 \text { tons to below } \\
12 \text { tons, excluding those that are used solely in connection with } \\
\text { agricultural activities carried out by an agricultural tax payer }\end{array}$ & 1624.72 & 1610.10 & 1640.70 & 1666.96 & $-0.90 \%$ & $1.90 \%$ & $1.60 \%$ \\
\hline 9 & $\begin{array}{l}\text { Trailers and semi-trailers, which together with the motor } \\
\text { vehicle have a maximum permissible weight of } 36 \text { tons }\end{array}$ & 1895.48 & 1878.43 & 1914.13 & 1944.76 & $-0.90 \%$ & $1.90 \%$ & $1.60 \%$ \\
\hline 10 & $\begin{array}{l}\text { Trailers and semi-trailers, which together with the motor } \\
\text { vehicle have a maximum permissible weight of over } 36 \text { tons }\end{array}$ & 2396.41 & 2374.85 & 2419.98 & 2458.7 & $-0.90 \%$ & $1.90 \%$ & $1.60 \%$ \\
\hline 11 & Buses less than 22 seats & 1918.50 & 1901.24 & 1937.37 & 1968.37 & $-0.90 \%$ & $1.90 \%$ & $1.60 \%$ \\
\hline 12 & Buses equal to or greater than 22 seats & 2425.51 & 2403.69 & 2449.37 & 2488.56 & $-0.90 \%$ & $1.90 \%$ & $1.60 \%$ \\
\hline
\end{tabular}

Source: own study based on the announcements of the Minister of Finance and the Minister of Finance and Development on the upper limits of specific taxes and local fees in the years 2016, 2017, 2018, 2019 (M.P. $z 2015$ r., item 735, M.P. z 2016 r., item 779, M.P. $z$ 2017 r., p item 800, M.P. $z$ 2018 item 745)

year. When setting the tax rates outside the criterion of revenue to the municipal budget, municipalities are also guided by environmental protection, for example by setting lower tax rates for vehicles with higher environmental standards. As a result, transport companies located in a given municipality are encouraged to replace their vehicles with vehicles meeting higher environmental standards. This plays a particularly important role in the analyzed tourist communes, which are interested in attracting new tourists who appreciate the climatic and tourist values of a given commune.

\section{Evaluation of revenues to the budgets of the analyzed communes in total}

The stable financing of the self-governments' own tasks depends primarily on the effective acquisition of funds from individual public levies as provided for in the legislation of a given country. The public authorities of particular local government units should take care of increasing the revenues of municipalities from the local taxes and fees due to them. Current and independent assessment of communes revenues is the basis for balancing the local government budget (Wildasin, 2012). Therefore, monitoring, controlling and auditing the revenue generated by a given tax is crucial to ensure the proper functioning of each municipality (Filipiak, 2006).

The supervision and control of local governments budgets is an important area of activity of the independent external audit institutions established for this purpose (in most countries) (Overview of external audit, 2018). Revenue from the municipal budget is examined by specialized organizational units of municipalities (control and audit). Specialized public entities, which act as external auditors of local governments budgets, also examine the revenues of municipalities in Poland. (e.g., Regional Chambers of Auditors).

The assessment of self-government revenues on the basis of financial statements prepared by the communes, carried out by independent auditors, makes it possible to diagnose threats to the implementation of the communes budget. Such activities have been carried out all over the world for many years, mainly in the United 
States of America, where an external audit carried out by auditing companies plays a very important role in this respect (Copley, 1991). Ongoing assessment of the municipalities revenues from local taxes and charges is carried out through information technology systems that accelerate the process of data collection and processing (Coderre, 2009). When analyzing income, it is also worthwhile to pay attention to the potential risks in this area (Borghesi, Gaudenzi, 2013).

The implementation of the assessment of the revenue to the municipal budget from the selected tax requires a general revenue survey (Pfaff, 2011). This is the basis for determining the share of the tax on means of transport in the total income to the budget of the analyzed local governments. The analysis of revenues to the communes budget is an element of the assessment of the revenues of local governments (New Jersey Manual of Audit Procedures, 2019).

Table 2 presents a general statement of income to the budgets of 11 communes of Pomorskie Voivodship in Poland in 2016-2019 (urban Gdańsk, Gdynia, Jastarnia, Łeba, Puck, Sopot, Ustka, Władysławowo and rural communes of Krokowa, Stegna and Ustka). A detailed breakdown is provided in Table 2 .

The concluded statement of total revenue to the budgets of the 11 municipalities under analysis ( 8 urban and 3 rural) from Pomorskie Voivodship in Poland Table 2 shows that all the communes under analysis recorded a general increase in revenue to the budget in 2019 in relation to the base year 2016. The highest revenue growth over the 4 years under analysis was recorded by the cities of Jastarnia and Władysławowo (a 33\% increase in 2019 in relation to 2016). The lowest increase in revenue in 2019 over the 4 years under consideration in relation to the base year 2016 was recorded by Łeba (increase by 9\% in 2019 compared to 2016). The highest dynamics in 2017-2019 in relation to the base year 2016 concerned the rural municipality of Stegna, which in 2018 achieved a $40 \%$ increase in total income compared to the base year 2016 .

In total, 5 municipalities recorded decreases in total income to the commune budget on an annual basis (year-on-year) in the audited period, including 20162019. 2\% drop in revenue in 2017 compared to in 2016, the city of Sopot (a nominal decrease of 4550823 PLN) and the rural municipality of Ustka (a nominal decrease of 793364 PLN in revenue) recorded. In 2018, none of the analyzed municipalities recorded a decrease in budget revenues in the annual perspective. Further declines in revenues to the municipalities budgets in the annual perspective occurred in 2019. 3 municipalities, the city of Ustka, recorded declines in revenues in 2019 as compared to 2018 (decrease in the following factors were taken into account: Stegna rural municipality (decrease by 6\%, nominal income decrease by 5921474 PLN), Stegna rural municipality (decrease by $13 \%$, nominal income decrease by 8135681 PLN) and Krokowa rural municipality (decrease by $13 \%$, nominal income decrease by 962729 PLN).

Generally speaking, it should be noted that out of the 11 assessed coastal communes of Pomorskie Voivodship in Poland, the total revenue-to-budget decreases in 2016-2019 concerned 2 urban communes (Sopot and Ustka) and 3 rural communes (Krokowa, Stegna and Ustka).

\section{Assessment of municipalities revenues from the tax on means of transport}

The next stage of the analysis is to assess the level of income to the budgets of the analyzed municipalities from the tax on means of transport. It should first be noted that, as mentioned above, the municipality sets the rates of the tax on means of transport on its own, taking into account certain criteria for setting the rate for a given tax subject. For example, when setting the tax rates on means of transport for 2016, the municipality of Gdańsk applied a reduced rate on a car meeting the environmental standard at the minimum level of EURO 2/II (Resolution No. XV/396/15, 2015). Similar reduced rates of tax on means of transport depending on combustion standards were applied, for example, in Sopot in 2019 for vehicles meeting the EURO 0, EURO 1/I, EURO 2/II, EURO 3/III, EURO 4/IV, EURO 5/V, EURO 6/VI standards (Law No II/12/2018, 2018).

It should be noted that the city of Sopot has the status of a health resort, so environmental protection and pro-ecological activities play a major role there. The preference for reduced rates of real estate tax for vehicles meeting high ecological standards results in a reduction of income to the budget of a given commune, however, at the same time improving environmental conditions in the commune. The above examples indicate that the tax on means of transport, apart from the income effect on the commune budget, is also an instrument of the communes influence on other key areas for the city, in this case on the state of the environment. The following Table 3 presents a summary of income to the budget of the analyzed communes from the tax on means of transport together with its share in the total income to the municipality budget.

An analysis of the data in Table 3 shows that revenues from the tax on means of transport constituted a small percentage of the total revenues to the budgets of the municipalities under analysis. None of the municipalities in 2016-2019 recorded revenues to the budget from the tax on means of transport at a level exceeding $1 \%$ of total budget revenues. The highest percentage share of the tax on means of transport in total revenues concerned the rural municipality of Ustka and was $0.67 \%$ in 2016 (nominal income of 327671 PLN) and in 2017 (nominal income - 319355 PLN). The lowest share of the tax on means of transport in the total income to the municipality budget was recorded in 2019 in the 


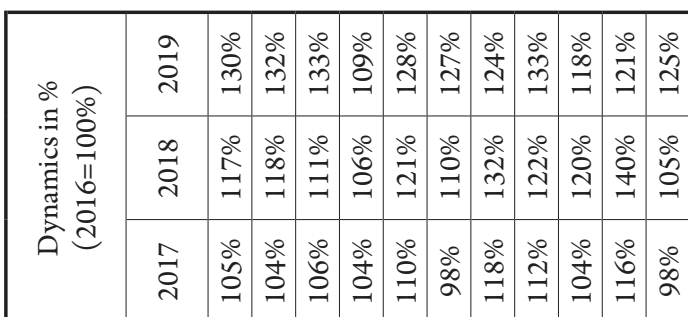

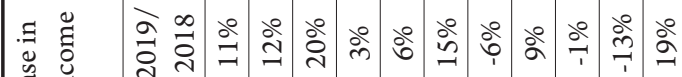
过卷 产表

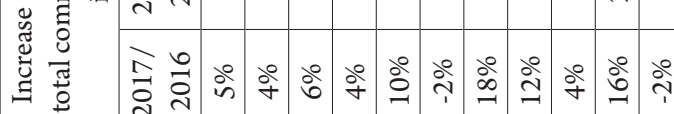

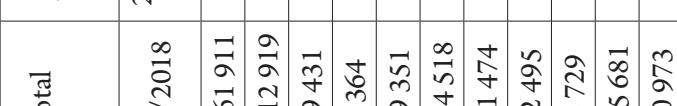

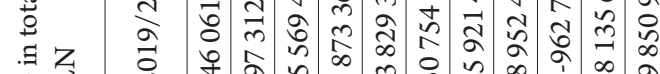

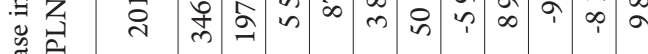

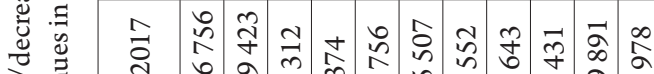

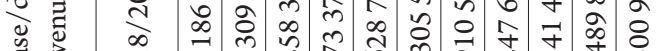

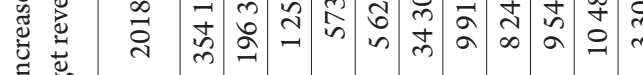

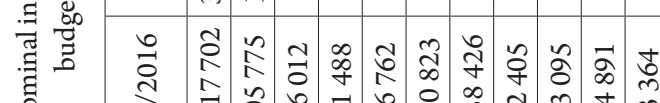

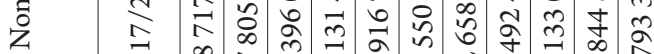

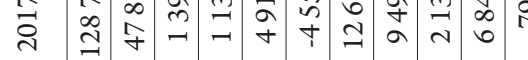

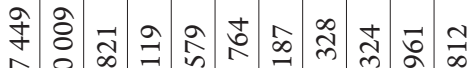
כ)

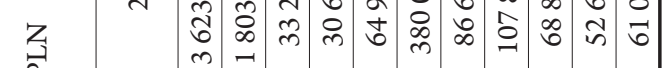

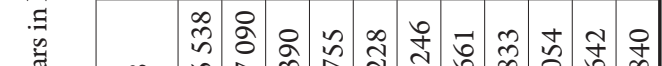

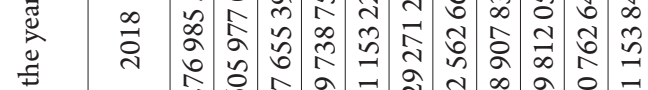

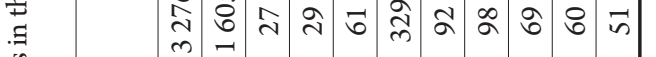

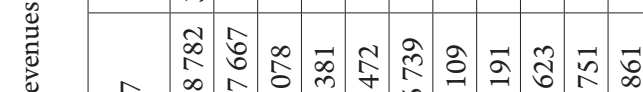

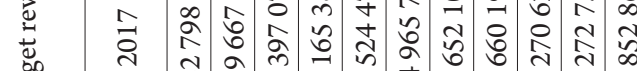

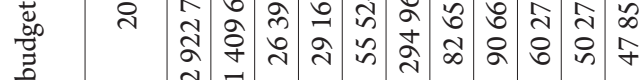
芯

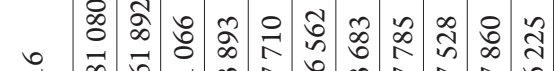

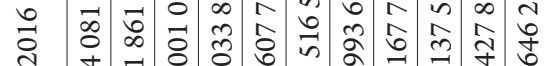

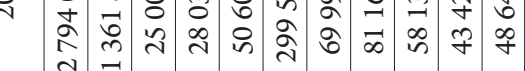

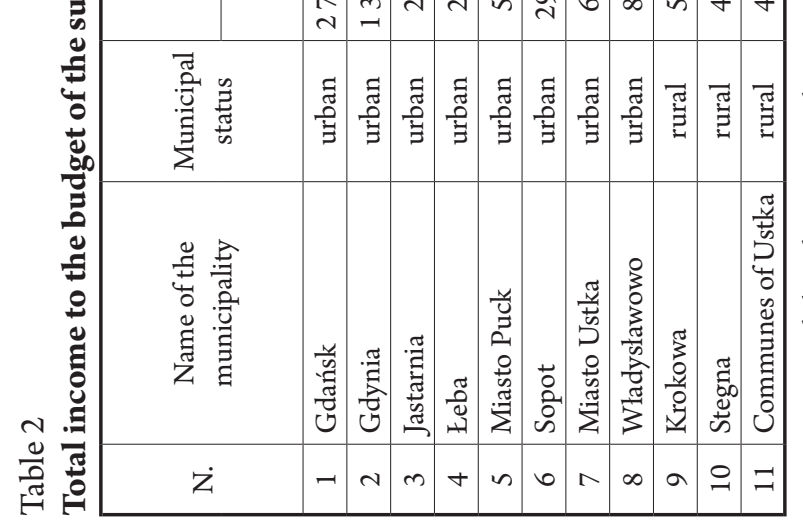

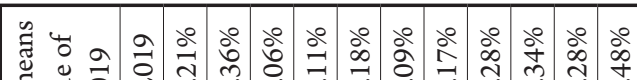
שू 苞 焉 นั

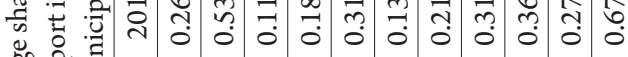
窇 毒

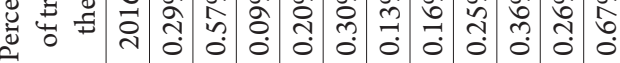

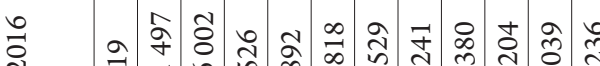

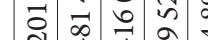

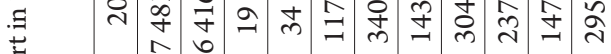

응

告 苟 $\quad$ o

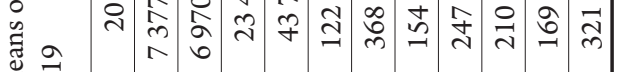
घ

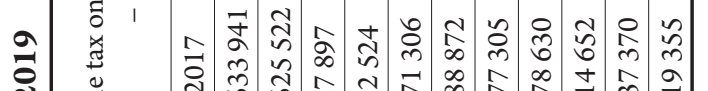

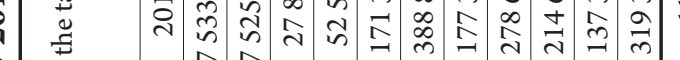

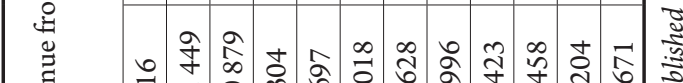
离 .

$\overrightarrow{9}$ F $\infty$

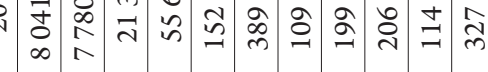

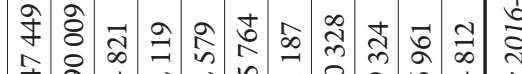

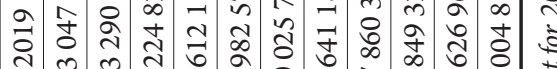

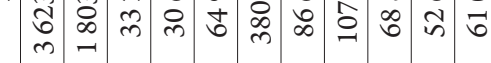

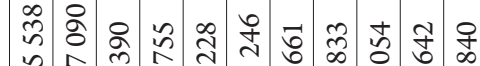

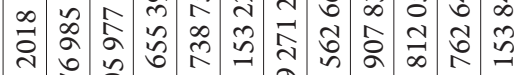
స్ర

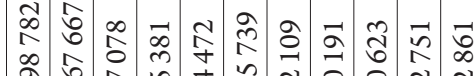

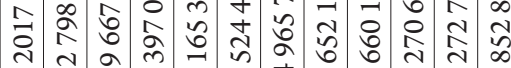

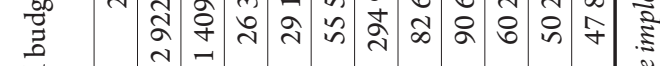
吾

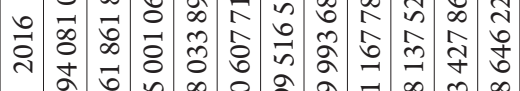
रิ

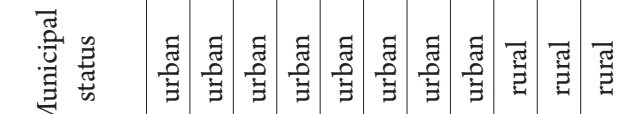

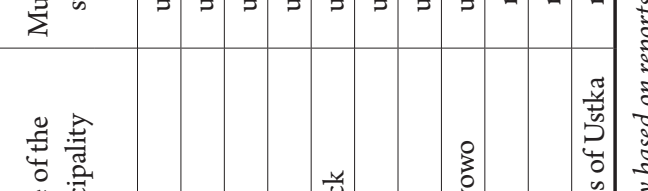
竞泀

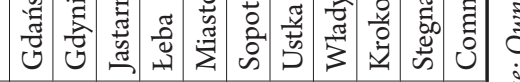




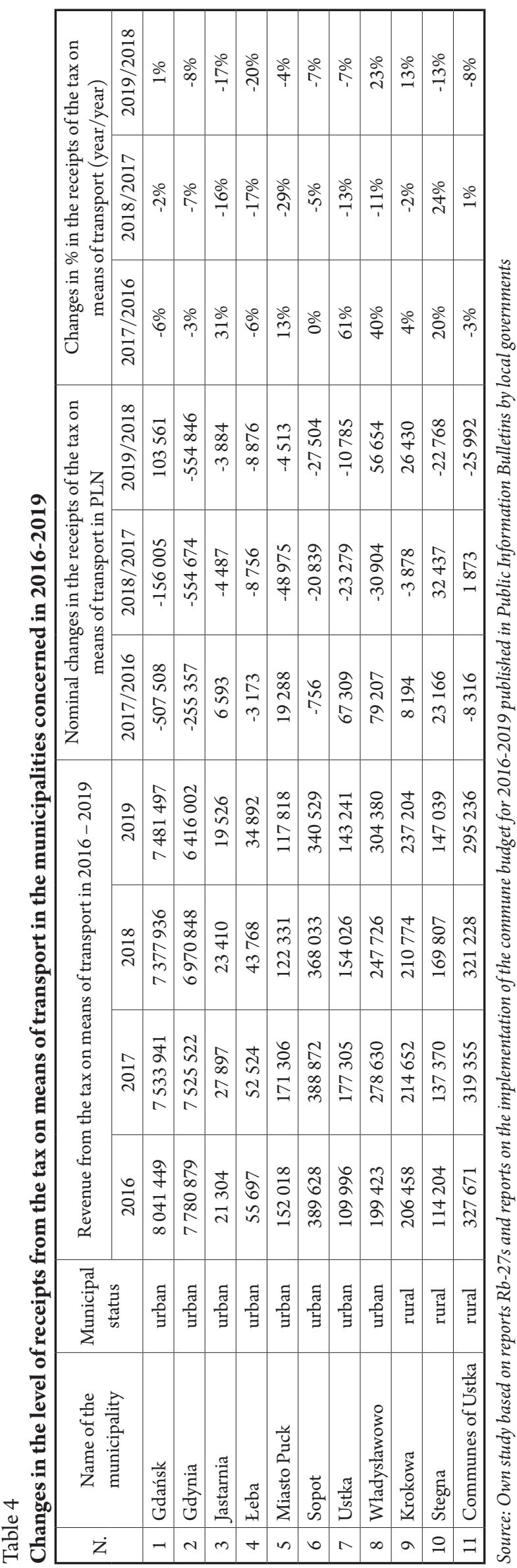

case of Jastarnia municipality, where it represented only $0.06 \%$ of the total income to the municipality budget. In the case of Jastarnia municipality, income from the tax on means of transport also in the remaining examined period represented a small share in the total income of the municipality ( $0.09 \%$ in $2016,0.11 \%$ in $2017,0.08 \%$ in 2018). Similarly, a small share of the tax on means of transport in the total income to the municipal budget was recorded in 2019 in Sopot, where it represented only $0.09 \%$ of the total income to the municipality budget. A very low share of income to the communes budgets from the tax on means of transport could result from the introduction of exemptions for vehicles with low exhaust emissions. The low share of the tax in question may also indicate that there are not many heavy goods vehicles in the area of the communes under analysis, and therefore no transport companies using this means of transport were located there either. Moreover, it should also be noted that the surveyed communes are located in a tourist attractive area, which determines the specificity of the local industry focused mainly on servicing tourists and not transporting goods. The exceptions are Gdańsk and Gdynia, where there are important sea ports for Poland. However, also in these cities, the share of the tax on means of transport constitutes a small share in revenues to the budgets of communes. Table 4 contains data on nominal and percentage changes in revenues to the budgets of the analysed municipalities from the tax on means of transport in 2016-2019.

The statement of revenue to the budgets of the 11 municipalities concerned from the tax on means of transport in nominal terms (presented in Table 4) indicates that during the period considered all municipalities recorded declines in income. The highest drop in revenue to the municipal budget from the tax on means of transport on an annual basis (year-onyear) occurred in Puck in 2018 (a 29\% drop in revenue compared to 2017).

Łeba was another municipality which recorded a large drop in revenue of $20 \%$ in annual terms, which occurred in 2019 (decrease in revenue compared to revenues in 2018). The two municipalities of Gdynia and Łeba recorded decreases in revenues from the tax on means of transport in three consecutive years (in 2017, 2018, 2019 as compared to the previous year). The data in Table 4 show a general downward trend in revenues from the vehicle tax in the surveyed municipalities. The decrease in the budget revenues from the tax on means of transport concerned 4 municipalities in 2017, while in 2018, the decrease in revenue concerned 9 municipalities. In 2019, 8 municipalities recorded a decrease in revenue from this tax.

The scale of changes in the level of income is interesting, as the city of Ustka in 2017 recorded a $61 \%$ increase in income from the analyzed tax The municipality of Władysławowo had a similarly high income of $40 \%$ in 2017 in comparison with 2016 . 
Unfortunately, both municipalities (the city of Ustka and Władysławowo) in 2018 recorded drops in income at the level of $11 \%-13 \%$ compared to 2017 , with Władysławowo commune increasing its revenue from this tax by $23 \%$ in 2019 compared to 2018 , when it recorded a decrease in revenue. The analysis of the surveyed municipalities indicates that there is a high risk related to the difficult forecasting of the level of income to the municipal budget from the tax on means of transport for the following year.

\section{Conclusions}

The assessment of revenues to the budgets of 11 analyzed communes indicates, that the tax on means of transport in the period under examination (covering the years 2016-2019) accounted for a small share in the total revenues to the municipal budgets (less than $1 \%$ of total budget revenues). The analyzed municipalities recorded a general decrease in revenues to the budgets from the tax on means of transport. Revenues from the analyzed tax are characterized by large annual fluctuations and a general trend of their decrease in particular years.

The unstable revenue from this tax indicates potential risks related to difficult financial planning of the assessed municipalities in the coming years. This is due to the aforementioned fluctuations in revenue levels and the trend towards lower budget revenues. It is worth noting, however, that according to the data under analysis, the tax on means of transport constitutes a small share in the total revenues to the municipal budget and therefore, the decrease in revenues from this title should not cause serious financial problems for individual municipalities under analysis.

The results of the research indicate that the tax on means of transport is not a significant source of budgetary revenue for the Polish municipalities. Moreover, the conducted research indicates that it is justified to continue the research on the evaluation of municipalities revenues in relation to other taxes and local fees.

\section{References:}

Antonio Borghesi, Barbara Gaudenzi (2013). Risk Management How to Assess, Transfer and Communicate Critical Risks, Springer-Verlag Italia.

Chojna-Duch, E. (2003). Polskie prawo finansowe. Finanse publiczne, LexisNexis, Warsaw.

Copley, P. A. (1991). The association between municipal disclosure practices and audit quality. Journal of Accounting and Public Policy, Volume 10, Issue 4, Winter 1991, p. 245-266.

Freire, M. E., \& Garzón, H. (2014). Managing Local Revenues [in:] Farvacque-Vitkovic C., Kopanyi M. (red.), Municipal Finances. A Handbook for Local Governments, International Bank for Reconstruction and Development / The World Bank, Washington DC, p. 147-213. Retrieved from: http://documents.worldbank.org/curated/ en/403951468180872451/pdf/Municipal-finances-a-handbook-for-local-governments.pdf

World Economic Outlook Reports, April 2020: Chapter 1. Retrieved from: https://www.imf.org/en/Publications/ WEO/Issues/2020/04/14/weo-april-2020.

Rudowicz, E. (2010). Dochody jednostek samorzadu terytorialneg. Podstawka M. (red.), Finanse. Instytucje, Instrumenty, Podmioty, Rynki, Regulacje, PWN, Warsaw 2010 r., p. 155-176.

Podstawka, M. (2011). Podstawy finansów. Teoria i praktyka. Warsaw University of Life Sciences (WULS - SGGW), Warsaw.

Wildasin, D. E. (2012). Urban Public Finance, Routledge Taylor\&Francis Group, New York, p. 65-68.

Filipiak B (2006). Istota, zakres i cechy finansów samorządu terytorialnego [in:] Dylewski M., Filipiak B., Gorzałczyńska-Koczkodaj M., Finanse Samorządowe. Narzędzia, Decyzje, Procesy, PWN, Warsaw.

J. Pfaff (2011). Rewizja finansowa, University of Economics in Katowice.

Coderre D. (2009). Internal audit, efficiency through automation. The Institute of Internal Auditors John Wiley \& Sons. Retrieved from: https://tse.ir/cms/Portals 1 1/I\%20A\%20TSE.pdf

New Jersey Manual of Audit Procedures (2019). State of New Jersey Department of the Treasury Division of Taxation. Retrieved from: https://www.state.nj.us/treasury/taxation/pdf/njmap.pdf

Overview of external audit systems in local government (2018). EUROSAI Task Force on Municipality Audit (TFMA). Retrieved from: http://www.eurosaiop.org/docs/upload/documents/TFMA_Overview_external_ audit_systems_2018_1555656170.pdf

The Act of 12 January 1991 on local taxes and fees (i.e., Journal of Laws of 2019, item 1170).

The Act of 27 August 2009 on public finance (i.e., Journal of Laws of 2019, item 869).

Act of March 8, 1990 on communal self-government (i.e. Journal of Laws of 2019, item 506).

Act of 13 November 2003 on the income of local government units (i.e. Journal of Laws of 2020, item 23).

Resolution No. XV / 396/15 of the Gdańsk City Council of October 29, 2015 on determining the amount of tax on means of transport in the city of Gdańsk (Journal of Laws of the Pomeranian Voivodship from 2015, item 3982). 